\title{
Punktdefekte im kubischen elastischen Kontinuum
}

\section{Doctoral Thesis}

Author(s):

Muggli, Jürg

Publication date:

1971

Permanent link:

https://doi.org/10.3929/ethz-a-000087824

Rights / license:

In Copyright - Non-Commercial Use Permitted 
Diss. Nr. 4595

\title{
Punktdefekte im kubischen elastischen Kontinuum
}

\author{
Abhandlung \\ zur Erlangung der Würde eines \\ Doktors der Naturwissenschaften \\ der
}

Eidgenössischen Technischen

Hochschule Zürich

\author{
vorgelegt von \\ Jürg Muggli \\ Dipl. Phys. ETH \\ geboren am 4. April 1943 \\ von Küsnacht und Bäretswil, Kanton Zürich
}

Angenommen auf Antrag von

Prof. Dr. W. Känzig, Referent

Prof. Dr. W. Baltensperger, Korreferent

\author{
Springer-Verlag \\ Berlin · Heidelberg • New York \\ 1971
}


Phys. kondens. Materie 12, 237-261 (1971)

(C) by Springer-Verlag 1971

\title{
Punktdefekte im kubischen elastischen Kontinuum
}

\author{
JÜRG MUgGLI \\ Laboratorium für Festkörperphysik der ETH Zürich
}

Eingegangen am 9. November 1970

\section{Point Defects in a Cubic Elastic Continuum}

The determination of the displacement and strain fields of a point defect in a cubic crystal requires even in the framework of continuum elasticity theory numerical calculation. These fields of elastic dipoles are expanded in suitable vector and tensor fields. The coefficients of this expansion are calculated up to polynomials of 5th and 4th order in the direction cosines using the ratios of elastic constants as parameters. With this expansion the interaction of elastic dipoles in a cubic medium can be calculated. The results have been applied to the interaction of $\mathrm{F}$-centres and of $\mathrm{O}_{\mathbf{2}}^{-}$-centres in alkali halides.

Die Auslenkungs- und Verzerrungsfelder von Punktdefekten in einem kubischen Kristall lassen sich auch im Rahmen der Kontinuumstheorie nur numerisch berechnen. Für elastische Dipole werden diese Felder nach geeigneten Vektor- bzw. Tensorfeldern entwickelt. Die Koeffizienten dieser Entwicklung sind für alle praktisch vorkommenden Verhältnisse der elastischen Konstanten berechnet bis zu Polynomen 5. bzw. 4. Ordnung in den Richtungscosinus. Damit kann die Wechselwirkung von elastischen Dipolen im kubischen Medium berechnet werden. Die Resultate wurden angewendet auf die Wechselwirkung von $0_{-}^{-}$-Zentren und von F-Zentren in Alkalihalogeniden.

Les champs de déplacement et de déformation produits par de défauts ponctuels dans un cristal cubique ne peuvent être calculés que numériquement même dans la théorie de l'élasticité des milieux continues. Ces champs d'un dipole élastique sont développés suivants des champs de vecteurs et de tenseurs adaptés à la symmetrie. Les coéfficients du développement sont calculés jusqu' aux polynomes du cinquième ou quatrième degré du cosinus de direction pour differentes proportions des constantes d'élasticité. On en a déduit l'interaction de dipoles élastiques dans des milieux cubiques. Les résultats ont été appliqués à l'interaction entre des centres $\mathrm{F}$ et à l'interaction des centres $\mathrm{O}_{\mathbf{2}}^{-}$dans les halogénures alkalins.

\section{Einleitung}

Lokale Störungen im gleichmäßigen Aufbau von Kristallgittern bewirken langreichweitige Verzerrungen des ganzen Gitters. In einer ersten Approximation lassen sich diese Verzerrungen im Rahmen der elastischen Kontinuumstheorie berechnen. Um die Veränderung des Gitters bei einer vorgegebenen Kraftdichteverteilung berechnen zu können, muß man das Fundamentalintegral (Monopolfeld oder Greenfunktion), d.h. die Veränderung des elastischen Kontinuums durch eine Punktkraft kennen. Im isotropen (siehe z. B. [1]) und im hexagonalen Fall (z. B. [2]) läßt sich das Fundamentalintegral geschlossen angeben. Daten über die Wechselwirkung von Punktdefekten sind aber vor allem für kubische Kristalle bekannt (z.B. $\mathrm{O}_{2}^{-}$Moleküle in Alkalihalogeniden [3]).

In der vorliegenden Arbeit wird nun das Fundamentalintegral nach Feldern entwickelt, die der kubischen Symmetrie angepaßt sind und sich als Linearkombi- 